\title{
PENGARUH PENERAPAN MODEL PEMBELAJARAN DISCOVERY LEARNING TERHADAP HASIL BELAJAR IPS PADA SISWA KELAS 4 SD
}

\author{
Firosalia Kristin \\ firosalia.kristin@gmail.com \\ Dwi Rahayu \\ dwi_rahayu@gmail.com \\ Program Studi PGSD - FKIP Universitas Kristen Satya Wacana Salatiga
}

\begin{abstract}
ABSTRAK
Penelitian ini bertujuan untuk mengetahui pengaruh penggunaan model discovery learning terhadap hasil belajar IPS kelas 4 SD Negeri Koripan 01. Jenis penelitian ini adalah penelitian eksperimen semu (Quasi Experimental Design). Subjek dalam penelitian ini adalah siswa kelas IV SD Negeri Koripan 01 sebagai kelas eksperimen dan siswa kelas 4 SD Negeri Koripan 04 sebagai kelas kontrol. Teknik pengumpulan data melalui observasi dan tes untuk mengukur hasil belajar IPS. Berdasarkan hasil penelitian dan analisis data, disimpulkan bahwa penggunaan model discovery learning berpengaruh terhadap hasil belajar IPS siswa kelas 4 SD Negeri Koripan 01. Hal ini ditunjukkan dengan hasil t hitung pada independent sample $t$ test yang telah dilakukan setelah treatment diperoleh signifikasi 0,000 lebih kecil dari $0,05(0,000<0,05)$, karena signifikansi 2-tailed pada independent sample t test lebih kecil dari 0,05 maka Ho ditolak dan $\mathrm{H} 1$ diterima.
\end{abstract}

Kata kunci: Discovery Learning, Hasil Belajar IPS

\section{PENDAHULUAN}

Kini semakin disadari bahwa pendidikan memainkan peranan yang sangat penting didalam kehidupan dan kemajuan umat manusia. Pendidikan merupakan suatu kekuatan yang dinamis dalam kehidupan setiap individu, yang mempengaruhi perkembangan fisiknya, daya, jiwa, sosial dan moralitasnya, atau dengan perkataan lain, pendidikan merupakan suatu kekuatan yang dinamis dalam mempengaruhi kemampuan, kepribadian dan kehidupan individu dalam pertemuan dan pergaulannya dengan sesama, serta hubungannya dengan Tuhan.

Keberhasilan dalam pembelajaran dipengaruhi oleh faktor-faktor yang terlibat dalam semua kegiatan belajar mengajar. Diantara faktor-faktor tersebut adalah siswa, guru, kebiajakan pemerintah dalam membuat kurikulum, serta dalam proses belajar seperti metoda, sarana dan prasarana (media pembelajaran), model, dan pendekatan belajar yang digunakan. Kondisi riil dalam pelaksanaannya latihan yang diberikan tidak sepenuhnya dapat meningkatkan kemampuan siswa dalam menerapkan konsep. Rendahnya mutu pembelajaran dapat diartikan kurang efektifnya proses pembelajaran. Penyebabnya dapat berasal dari siswa, guru 
maupun sarana dan prasarana yang ada, minat dan motivasi siswa yang rendah, kinerja guru yang rendah, serta sarana dan prasarana yang kurang memadai akan menyebabkan pembelajaran menjadi kurang efektif. Saat sekarang ini sistem pembelajaran harus sesuai dengan kurikulum yang menggunakan sistem KTSP (Kurikulum Tingkat Kesatuan Pendidikan). Jadi pendidikan tidak hanya ditekankan pada aspek kognitif saja tetapi juga afektif dan psikomotorik.

Permasalahan yang dialami dalam mata pelajaran Ilmu Pengetahuan Sosial meliputi faktor internal dan faktor eksternal.Faktor internal yang dialamai oleh siswa meliputi hal-hal seperti; sikap terhadap belajar, motivasi belajar, konsentrasi belajar, kemampuan mengolah bahan belajar, kemampuan menyimpan perolehan hasil belajar, kemampuan menggali hasil belajar yang tersimpan, kemampuan berprestasi atau unjuk hasil belajar, rasa percaya diri siswa, intelegensi dan keberhasilan belajar, kebiasaan belajar dan cita-cita siswa. Faktor-faktor internal ini akan menjadi masalah sejauh siswa tidak dapat menghasilkan tindak belajar yang menghasilkan hasil belajar yang baik (Dimyati \& Mudjiono, 2002).

Faktor eksternal meliputi hal-hal sebagai berikut; guru sebagai pembimbing belajar, prasarana dan sarana pembelajaran, kebijakan penilaian, lingkungan siswa di sekolah, dan kurikulum sekolah. Dari sisi guru sebagai pembelajar maka peranan guru dalam mengatasi masalah-masalah eksternal belajar merupakan prasyarat terlaksanannya siswa dapat belajar (Dimyati \& Mudjiono, 2002).

Masih rendahnya hasil belajar IPS disebabkan oleh masih dominannya skill menghafal darIPSda skill memproses sendiri pemahaman suatu materi. Selama ini, minat belajar siswa terhadap mata pelajaran Ilmu Pengetahuan Sosial (IPS) masih tergolong sangat rendah. Hal ini dapat dilihat pada sikap siswa selama mengikuti proses pembelajaran tidak fokus dan ramai sendiri. Bahkan ada sebagian siswa yang menganggap mata pelajaran IPS tidak begitu penting dikarenakan tidak masuk pada mata pelajaran yang diujikan pada Ujian Nasional (UN). Faktor minat itu juga dipengaruhi oleh adanya metode mengajar yang digunakan guru dalam menyampaikan materi. Metode yang konvensional seperti menjelaskan materi secara abstrak, hafalan materi dan ceramah dengan komunikasi satu arah, yang aktif masih didominasi oleh pengajar, sedangkan siswa biasanya hanya memfokuskan penglihatan dan pendengaran. Kondisi pembelajaran seperti inilah yang mengakibatkan siswa kurang aktif dan pembelajaran yang dilakukan kurang efektif. Disini guru dituntut untuk pandai menciptakan suasana pembelajaran yang menyenangkan bagi siswa sehingga siswa kembali berminat mengikuti kegiatan belajar.

Berdasarkan hasil observasi di SD Negeri Koripan 01 dan wawancara kepada wali kelas 4 bahwa masih banyak siswa yang belum memenuhi KKM, masih banyak kekurangan dalam proses pembelajaran. Saat proses belajar mengajar sebagian siswa mengalami kesulitan dalam pemahaman konsep, karena tidak 
terdorong untuk mengembangkan kemampuan berfikirnya. Dalam proses belajar mengajar sebagian besar materi disampaikan dengan menggunakan model ceramah dan tanya jawab sehingga siswa kurang antusias dalam pembelajaran dan kurang memahami materi. Selain itu siswa cenderung pasif, kurang percaya diri jika diberi kesempatan untuk bertanya, jika melakukan kesalahan siswa akan cenderung putus asa, dan takut membuat kesalahan jika diminta menyampaikan pendapat serta kebanyakan siswa meniru jawaban dari jawaban siswa lain jika diberi pertanyaan. Dalam pembelajaran ini konsep yang diterima siswa hampir semuanya berasal dari apa yang dikatakan oleh guru. Siswa kurang didorong untuk aktif atau cenderung pasif dalam mengikuti pembelajaran sehingga mengakibatkan pembelajaran kurang menarik dan membosankan yang mengakibatkan tingkat pemahaman siswa menjadi rendah dan berdampak terhadap hasil belajar siswa yang rendah. Hal ini terlihat di SD Negeri Koripan 01 pada beberapa tes IPS yang telah dilakukan, masih kurang dari $75 \%$ siswa yang memenuhi standar ketuntasan $\geq$ Kriteria Ketuntasan Minimal yaitu 71. Dari jumlah 24 diketahui hanya 9 siswa yang nilainya $\geq 71$ yang diatas KKM dan 15 siswa lainnya $<71$. Berdasarkan data menunjukkan bahwa, yang mencapai KKM adalah $38 \%$ sedangkan yang belum memenuhi KKM adalah $62 \%$.

Berdasarkan hasil pra penelitian yang telah dilakukan di SD Negeri Koripan 01 tersebut, nampak bahwa guru perlu memilih model pembelajaran yang tepat, kreatif dan inovatif dalam pembelajaran yang dapat menumbuhkan rasa antusias dan menyenangkan, menciptakan kondisi belajar yang kondusif, melibatkan siswa secara aktif dalam pembelajaran sehingga konsep dan materi pelajaran yang disampaikan dapat diterima dengan baik dan siswa dapat mencapai ketuntasan belajar yang telah ditentukan. Penerapan model discovery learning dapat dijadikan sebagai salah satu alternatif untuk mengatasi permasalahan di atas. Pembelajaran discovery learning adalah suatu model untuk mengembangkan cara belajar siswa aktif dengan menemukan sendiri, menyelidiki sendiri, maka hasil yang diperoleh akan setia dan tahan lama dalam ingatan, tidak akan mudah dilupakan oleh siswa. Dengan belajar penemuan, anak juga bisa berfikir lebih kritis dan mencoba memecahkan sendiri masalah yang dihadapi. Kebiasaan ini akan ditransfer dalam kehidupan masyarakat.

Model discovery learning dalam pembelajarannya dapat mendorong siswa untuk melakukan penyeledikan guna menemukan kebenaran ilmiah, bukan diajak. Jerome Brunner (Hosnan, 2014: 281) mengungkapkan bahwa model discovery learning adalah model yang mendorong siswa untuk mengajukan pertanyaan dan menarik kesimpulan dari prinsip-prinsip umum praktis contoh pengalaman. J.Brunner memakai cara dengan apa yang disebutnya discovery learning, yaitu murid mengorganisasikan bahan yang dipelajari dengan suatu bentuk akhir.

Menurut Bell (Hosnan, 2014: 281), belajar penemuan adalah belajar yang terjadi sebagai hasil dari siswa memanipulasi, membuat struktur dan 
mentransformasikan informasi sedemikian sehingga ia menemukan informasi baru. Dalam belajar penemuan, siswa dapat membuat perkiraan (conjucture), merumuskan suatu hipotesis dan menemukan kebenaran dengan menggunakan proses induktif atau proses deduktif, melakukan observasi dan membuat masalah.

Penggunaan model pembelajaran sangat diutamakan guna menimbulkan gairah belajar, motivasi belajar, merangsang siswa berperan aktif dalam proses pembelajaran. Melalui model discovery learning diharapkan dapat lebih mempermudah pemahaman materi pelajaran yang diberikan dan nantinya dapat mempertinggi kualitas proses pembelajaran yang selanjutnya dapat meningkatkan hasil belajar siswa.

Berdasarkan masalah tersebut peneliti tertarik melakukan penelitian eksperimen yang berjudul "Pengaruh Penerapan Model Discovery Learning Terhadap Hasil Belajar IPS Pada Siswa Kelas 4 SD".

Berdasarkan uraian diatas, maka rumusan masalah dalam penelitian ini adalah "Apakah terdapat pengaruh penggunaan model discovery learning terhadap hasil belajar IPS kelas 4 SD”.

\section{METODE PENELITIAN}

Penelitian ini adalah penelitian eksperimen. Penelitian eksperimen bertujuan untuk menyelidiki pengaruh terhadap hubungan sebab akibat, dengan cara memberikan perlakuan-perlakuan yang berbeda pada beberapa kelompok eksperimen dan menyediakan kontrol untuk perbandingan. Hasilnya dibandingkan dengan satu atau lebih kelas kontrol yang dikenai dengan perlakukan lain. Jenis penelitian ini adalah penelitian eksperimen semu (Quasi Experimental Design). Bentuk desain eksperimen ini merupakan pengembangan dari true experimental design, yang sulit dilaksanakan. Hal ini dikarenakan desain penelitian ini menggunakan kelompok eksperimen dan kelompok kontrol dimana keadaan kedua kelas tersebut dalam keadaan seimbang atau bisa dikatakan sama dalam bidang prestasi. Desain ini mempunyai kelompok kontrol, tetapi tidak dapat berfungsi sepenuhnya untuk mengontrol variabel-variabel luar yang mempengaruhi pelaksanaan eksperimen (Sugiyono, 2010: 114).

Penelitian ini dilaksanakan di kelas 4 SD Negeri Koripan 01, Desa Semagu, Kecamatan Susukan, Kabupaten Semarang sebagai kelas eksperimen yang mempunyai 9 guru PNS dan 1 guru honorer. Sebagai kelas kontrol akan dilaksanakan di SD Negeri Koripann 04, Desa Krandon, Kecamatan Susukan, Kabupaten Semarang. Kedua SD tersebut terletak dalam satu gugus, jarak antar kedua SD hanya sekitar $1 \mathrm{KM}$.

Data dalam penelitian ini menggunakan teknik Tes dan observasi. Teknik tes dalam penelitian ini digunakan untuk mengukur hasil belajar dari kelas yang dikenai 
treatment (lihat Lampiran 1). Observasi dilakukan peneliti selama proses pembelajaran berlangsung untuk mengetahui proses penerapan model discovery learning pada siswa kelas 4 SD Negeri Koripan 01. Untuk mengamati proses pembelajaran yang berlangsung dengan seksama serta memantau perkembangan siswa dari waktu ke waktu, maka digunakan lembar instrumen observasi (lampiran 2). Teknik analisis yang digunakan dalam penelitian ini adalah uji t untuk sampel independen (independent sample $t$ test). Analisis ini digunakan untuk mengetahui signifikansi perbedaan antara kelas kontrol dan kelas eksperimen sebelum dan sesudah perlakuan. Sebelum perlakuan (pre test) diharapkan kedua kelompok itu tidak berbeda secara signifikan.

\section{HASIL PENELITIAN DAN PEMBAHASAN}

Uji hipotesis dilakukan dengan uji-t pada masing-masing kelompok data, baik kelas eksperimen maupun kelas kontrol. Hasil uji hipotesis dikatakan signifikan apabila $\mathrm{t}_{\text {hitung }}>$ dari $\mathrm{t}_{\text {tabel }}$ dengan $\mathrm{db}=(\mathrm{n}-1)$ pada taraf signifikansi $(\alpha)=$ 0,05 . Namun sebelum uji dilaksanakan, terlebih dahulu hitung normalitas dan homogenitas dan homogenitas data gain. Untuk mengetahui data tersebut nomal, maka dilakukan uji kolmogorov-smirnov dengan bantuan SPSS 16. Hasil uji normalitas menunjukan bahwa sig. pada kelas kontrol dan kelas eksperimen masing-masing adalah 0,488 dan 0,749 nilai signifikansi kedua kelas tersebut lebih dari 0,05 , maka menunjukan bahwa data hasil belajar yang diperoleh dari kelas eksperimen dan kelas kontrol berdistribusi normal.

Berdasarkan hasil t-hitung menggunakan menggunakan signifikansi 2-tailed pada independent sample test yang telah dilakukan setelah treatmen diperoleh signifikasi 0,000 lebih kecil dari $0,05 \quad(0,000<0,05)$. Karena menggunakan signifikansi 2-tailed pada independent sample test lebih kecil dari 0,05 maka Ho ditolak dan $\mathrm{H}_{1}$ diterima. Dari hasil tersebut dapat disimpulkan bahwa terdapat perbedaan pengaruh penggunaan model discovery learning terhadap hasil belajar IPS kelas 4 SD. Hal ini diperkuat dengan informasi yang memaparkan nilai rata-rata hasil belajar IPS, bahwa nilai rata-rata siswa kelas eksperimen nilainya lebih tinggi dari pada nilai siswa kelas kontrol. Rata-rata nilai kelas eksperimen sebesar 82,08 sedangkan untuk kelas kontrol nilai rata-ratanya 70,22. Jadi penggunaan model pembelajaran model discovery learning berpengaruh terhadap hasil belajar IPS siswa kelas 4 SD Negeri Koripan 01.

Proses pembelajaran yang dilakukan melalui langkah-langkah berikut ini; pemberian rangsang, mengidentifikasi masalah, pengumpulan data, pengolahan data, pembuktian, dan menarik kesimpulan. Dalam pemberian rangsang siswa dihadapkan pada sesuatu yang menimbulkan kebingungannya, kemudian dilanjutkan untuk tidak memberi generalisasi, agar timbul keinginan untuk menyelidiki sendiri. Setelah itu mengidentifikasi masalah, guru memberi 
kesempatan kepada siswa untuk mengidentifikasi sebanyak mungkin agenda-agenda masalah yang relevan dengan bahan pelajaran, kemudian salah satunya dipilih dan dirumuskan dalam bentuk hipotesis (jawaban sementara atas pertanyaan masalah). Untuk menjawab permasalahan yang diberikan siswa terlebih dahulu mengumpulkan informasi sebanyak-banyaknya yang relevan untuk membuktikan benar atau tidaknya hipotesis. Selanjutnya siswa melakukan pengolahan data dengan percobaan untuk menemukan konsep-konsep atau prinsip-prinsip yang telah dirancang oleh guru dalam bentuk pertanyaan yang disediakan di lembar kerja siswa. Hasil kegiatan percobaan dianalisis dan ditulis dalam lembar kerja siswa. Setiap kelompok mempresentasikan hasil yang diperoleh dan membuktikan hasil yang diperoleh kepada teman satu kelas. Dalam model pembelajaran discovery learning, guru harus merencanakan dan menyiapkan alat dan bahan yang akan digunakan, memeriksa kesiapan siswa serta membantu siswa yang mengalami kesulitan supaya proses pembelajaran dapat berjalan dengan baik.

Model discovery learning merupakan suatu model pembelajaran melalui penemuan. Model ini menekankan pentingnya pemahaman struktur atau ide-ide penting terhadap suatu disiplin ilmu, melalui keterlibatan siswa secara aktif dalam proses pembelajaran. Jerome Brunner (Hosnan,2014:281) mengungkapkan bahwa model discovery learning adalah model yang mendorong siswa untuk mengajukan pertanyaan dan menarik kesimpulan dari prinsip-prinsip umum praktis contoh pengalaman. Belajar penemuan adalah belajar yang terjadi sebagai hasil dari siswa memanipulasi, membuat struktur dan mentransformasikan informasi sedemikian sehingga ia menemukan informasi baru. Dalam belajar penemuan, siswa dapat membuat perkiraan (conjucture), merumuskan suatu hipotesis dan menemukan kebenaran dengan menggunakan proses induktif atau proses deduktif, melakukan observasi dan membuat masalah (Hosnan,2014:281). Model discovery learning adalah memahami konsep, arti, dan hubungan, melalui proses intuitif untuk akhirnya sampai kepada suatu kesimpulan. Discovery learning terjadi bila individu terlibat, terutama dalam penggunaan proses mentalnya untuk menemukan beberapa konsep dan prinsip. Discovery learning dilakukan melalui observasi, klasifikasi, pengukuran, prediksi, dan penentuan.

Roestiyah (2001: 20) mengemukakan model discovery learning adalah model mengajar mempergunakan teknik penemuan. Model discovery learning adalah proses mental dimana siswa mengasimilasi suatu konsep atau prinsip. Proses mental tersebut misalnya mengamati, menggolongkan, membuat dugaan, menjelaskan, mengukur, membuat kesimpulan, dan sebagaimya. Dalam teknik ini siswa dibiarkan menemukan sendiri atau mengalami proses mental itu sendiri, guru hanya membimbing dan memberikan instruksi. Model pembelajaran discovery learning adalah model mengajar yang mengatur pengajaran sedemikian rupa sehingga anak memperoleh pengetahuan yang sebelumnya belum diketahuinya itu 
tidak melalui pemberitahuan, sebagian atau seluruhnya ditemukan sendiri. Dalam pembelajaran discovery learning kegiatan atau pembelajaran yang dirancang sedemikian rupa sehingga siswa dapat menemukan konsep-konsep dan prinsipprinsip melalui proses mentalnya sendiri.

Kelebihan dalam pembelajaran discovery learning siswa aktif dalam kegiatan belajar, sebab ia berfikir dan menggunakan kemampuan untuk menemukan hasil akhir. Siswa memahami benar bahan pelajaran, sebab mengalami sendiri proses menemukannya. Sesuatu yang diperoleh dengan cara ini lebih lama diingat, proses menemukan sendiri menimbulkan rasa puas siswa. Kepuasan batin ini mendorong ingin melakukan penemuan lagi sehingga minat belajarnya meningkat. Siswa yang memperoleh pengetahuan dengan penemuan akan lebih mampu mentransfer pengetahuannya ke berbagai konteks. Dalam pembelajaran discovery learning juga terdapat kendala yang dihadapi siswa, kendala ini menjadi kekurangan dalam pembelajaran discovery learning. Kendala yang dihadapi misalnya membutuhkan waktu belajar yang lebih lama dibandingkan dengan belajar menerima. Untuk mengurangi kelemahan tersebut maka diperlukan bantuan guru. Bantuan guru dapat dimulai dengan mengajukan beberapa pertanyaan dengan memberikan informasi secara singkat. Pertanyaan dan informasi tersebut dapat dimuat dalam lembar kerja siswa (LKS) yang telah dipersiapkan oleh guru sebelum pembelajaran dimulai.

\section{SIMPULAN}

Berdasarkan hasil penelitian dan analisis data, disimpulkan bahwa penggunaan model discovery learning berpengaruh terhadap hasil belajar IPS siswa kelas IV SD. Hal ini ditunjukkan dengan hasil t hitung menggunakan signifikansi 2tailed pada independent sample test yang telah dilakukan setelah treatmen diperoleh signifikasi 0,000 lebih kecil dari 0,05 $(0,000<0,05)$, karena signifikansi 2tailed pada independent sample test lebih kecil dari 0,05 maka Ho ditolak dan H1 diterima.

\section{DAFTAR PUSTAKA}

Dimyati \& Mudjiono. 2002. Belajar dan Pembelajaran. Jakarta: Rineka Cipta.

Hosnan. 2014. Pendekatan Saintifik dan Kontekstual dalam Pembelajaran Abad 21. Yogyakarta: Ghalia Indonesia.

Sugiyono. 2010. Statistika Untuk Penelitian. Bandung: Alfabeta.

Roestiyah. 2001. Strategi Belajar Mengajar. Jakarta: CV Maulana. 


\section{Lampiran 1.}

\section{Kisi-kisi Instrumen Tes}

\begin{tabular}{|c|c|c|c|}
\hline $\begin{array}{c}\text { Standar } \\
\text { kompetensi }\end{array}$ & $\begin{array}{c}\text { Kompetensi } \\
\text { dasar }\end{array}$ & Indikator & No item \\
\hline \multirow{7}{*}{$\begin{array}{l}\text { Mengenal } \\
\text { sumber daya } \\
\text { alam } \\
\text { kegiatan } \\
\text { ekonomi, } \\
\text { dan } \\
\text { kemajuan } \\
\text { teknologi } \\
\text { dilingkungan } \\
\text { kabupaten/k } \\
\text { ota dan } \\
\text { provinsi }\end{array}$} & \multirow{3}{*}{$\begin{array}{l}\text { Mengenal } \\
\text { perkembangan } \\
\text { teknologi } \\
\text { produksi, } \\
\text { komunikasi dan } \\
\text { transportasi serta } \\
\text { pengalaman } \\
\text { menggunakannya }\end{array}$} & $\begin{array}{l}\text { 1. Membandingkan persamaan } \\
\text { dan perbedaan jenis-jenis } \\
\text { teknologi produksi yang } \\
\text { digunakan masyarakat pada } \\
\text { masa lalu dan masa kini }\end{array}$ & $\begin{array}{l}1,2,3,4,5,6 \\
, 7\end{array}$ \\
\hline & & $\begin{array}{l}\text { 2. Membandingkan persamaan } \\
\text { dan perbedaan jenis-jenis } \\
\text { teknologi produksi yang } \\
\text { digunakan masyarakat pada } \\
\text { masa lalu dan masa kini }\end{array}$ & $\begin{array}{l}8,9,10,11, \\
12,13,14\end{array}$ \\
\hline & & $\begin{array}{l}\text { 3. Membandingkan persamaan } \\
\text { dan perbedaan jenis-jenis } \\
\text { teknologi produksi yang } \\
\text { digunakan masyarakat pada } \\
\text { masa lalu dan masa kini }\end{array}$ & $\begin{array}{l}15,16,17,1 \\
8,19,20\end{array}$ \\
\hline & \multirow{3}{*}{$\begin{array}{l}\text { Mengenal } \\
\text { permasalahan } \\
\text { sosial daerahnya. }\end{array}$} & $\begin{array}{l}\text { 4. Mendefinisikan pengertian } \\
\text { masalah sosial yang terjadi } \\
\text { didaerahnya. }\end{array}$ & $\begin{array}{l}1,2,3,4,5,6 \\
, 7\end{array}$ \\
\hline & & $\begin{array}{l}\text { 5. Mengenali ciri-ciri masalah } \\
\text { sosial }\end{array}$ & $\begin{array}{l}8,9,10,11, \\
12,13,14\end{array}$ \\
\hline & & $\begin{array}{l}\text { 6. Menentukan jenis masalah } \\
\text { sosial dilingkungan setempat. }\end{array}$ & $\begin{array}{l}15,16,17,1 \\
8,19,20\end{array}$ \\
\hline & \multicolumn{3}{|c|}{ Jumlah } \\
\hline
\end{tabular}

Lampiran 2.

Kisi-kisi Lembar Observasi

\begin{tabular}{|c|c|c|}
\hline Aspek & Indikator & Nomor \\
\hline \multirow[t]{2}{*}{ Pra pembelajaran } & Menyiapkan ruangan & \multirow[t]{2}{*}{1,2} \\
\hline & $\begin{array}{l}\text { Menyiapkan peserta didik untuk mengikuti } \\
\text { pembelajaran }\end{array}$ & \\
\hline \multirow[t]{2}{*}{ Membuka Pembelajaran } & Melakukan kegiatan apersepsi & \multirow[t]{2}{*}{3,4} \\
\hline & $\begin{array}{l}\text { Menyampaikan kompetensi (tujuan) yang akan } \\
\text { dicapai dan rencana kegiatan }\end{array}$ & \\
\hline \multicolumn{3}{|c|}{ Kegiatan Inti Pembelajaran } \\
\hline \multirow{2}{*}{$\begin{array}{l}\text { Penguasaan Materi } \\
\text { Pelajaran }\end{array}$} & Menunjukkan penguasaan materi pembelajaran & \multirow[t]{2}{*}{$5,6,7,8$} \\
\hline & $\begin{array}{l}\text { Mengaitkan materi dengan pengetahuan lain } \\
\text { yang relevan }\end{array}$ & \\
\hline
\end{tabular}


Pengaruh Penerapan Model Pembelajaran Dicsovery Learning Terhadap Hasil Belajar IPS Pada Siswa Kelas 4 SD (Firosalia Kristin \& Dwi Rahayu)

\begin{tabular}{|c|c|c|}
\hline & $\begin{array}{l}\text { Menyampaikan materi sesuai dengan hierarki } \\
\text { belajar }\end{array}$ & \\
\hline & Mengaitkan materi dengan realitas kehidupan & \\
\hline \multirow{7}{*}{$\begin{array}{l}\text { Pendekatan/strategi } \\
\text { pembelajaran }\end{array}$} & $\begin{array}{l}\text { Melaksanakan pembelajaran sesuai dengan } \\
\text { kompetensi (tujuan) yang akan dicapai }\end{array}$ & \multirow{7}{*}{$\begin{array}{l}9,10,11, \\
12,13, \\
14,15\end{array}$} \\
\hline & $\begin{array}{l}\text { Melaksanakan pembelajaran sesuai dengan } \\
\text { tingkat perkembangan dan kebutuhan siswa }\end{array}$ & \\
\hline & $\begin{array}{l}\text { Melaksanakan pembelajaran model discovery } \\
\text { learning secara runtut }\end{array}$ & \\
\hline & Menguasai kelas & \\
\hline & $\begin{array}{l}\text { Melaksanakan pembelajaran yang bersifat } \\
\text { kontekstual }\end{array}$ & \\
\hline & $\begin{array}{l}\text { Melaksanakan pembelajaran yang } \\
\text { memungkinkan tumbuhnya kebiasaan positif }\end{array}$ & \\
\hline & $\begin{array}{l}\text { Melaksanakan pembelajaran sesuai dengan } \\
\text { waktu yang telah dialokasikan }\end{array}$ & \\
\hline \multirow{4}{*}{$\begin{array}{l}\text { Pemanfaatan media } \\
\text { pembelajaran/sumber } \\
\text { belajar }\end{array}$} & $\begin{array}{l}\text { Menunjukkan keterampilan dalam penggunaan } \\
\text { media }\end{array}$ & \multirow[t]{4}{*}{$\begin{array}{l}16,17, \\
18,19\end{array}$} \\
\hline & Menghasilkan pesan yang menarik & \\
\hline & Menggunakan media secara efektif dan efisien & \\
\hline & Melibatkan siswa dalam pemanfaatan media & \\
\hline \multirow{6}{*}{$\begin{array}{l}\text { Pembelajaran yang } \\
\text { memicu dan } \\
\text { memelihara keterlibatan } \\
\text { siswa }\end{array}$} & $\begin{array}{l}\text { Menumbuhkan partisIPSsi aktif siswa dalam } \\
\text { pembelajaran }\end{array}$ & \multirow{6}{*}{$\begin{array}{l}20, \quad 21, \\
22, \quad 23, \\
24,25\end{array}$} \\
\hline & Merespons positif partisIPSsi siswa & \\
\hline & $\begin{array}{l}\text { Memfasilitasi terjadinya interaksi guru, siswa, } \\
\text { dan sumber belajar }\end{array}$ & \\
\hline & $\begin{array}{l}\text { Menunjukkan sikap terbuka terhadap respons } \\
\text { siswa }\end{array}$ & \\
\hline & $\begin{array}{l}\text { Menunjukkan hubungan antar pribadi yang } \\
\text { kondusif }\end{array}$ & \\
\hline & $\begin{array}{l}\text { Menumbuhkan keceriaan dan antusisme siswa } \\
\text { dalam belajar }\end{array}$ & \\
\hline \multirow[b]{2}{*}{$\begin{array}{l}\text { Penilaian proses dan } \\
\text { hasil belajar }\end{array}$} & Memantau kemajuan belajar & \multirow[t]{2}{*}{26,27} \\
\hline & $\begin{array}{l}\text { Melakukan penilaian akhir sesuai dengan } \\
\text { kompetensi (tujuan) }\end{array}$ & \\
\hline \multirow[t]{3}{*}{ Penggunaan bahasa } & $\begin{array}{l}\text { Menggunakan bahasa lisan secara jelas dan } \\
\text { lancar }\end{array}$ & \multirow{3}{*}{$\begin{array}{l}28, \quad 29, \\
30, \quad 31, \\
32,33\end{array}$} \\
\hline & Menggunakan bahasa tulis yang baik dan benar & \\
\hline & Menyampaikan pesan dengan gaya yang sesuai & \\
\hline \multirow{3}{*}{ Penutup } & $\begin{array}{l}\text { Melakukan refleksi pembelajaran dengan } \\
\text { melibatkan siswa }\end{array}$ & \multirow[t]{3}{*}{$\begin{array}{l}31, \quad 32, \\
33\end{array}$} \\
\hline & $\begin{array}{l}\text { Menyusun rangkuman dengan melibatkan } \\
\text { siswa }\end{array}$ & \\
\hline & Melaksanakan tindak lanjut & \\
\hline \multicolumn{2}{|l|}{ Total } & 33 \\
\hline
\end{tabular}

